\title{
KEWENANGAN DEWAN KEHORMATAN PENYELENGGARA PEMILU ( DKPP ) DALAM MENEGAKAN KODE ETIK PELANGGARAN PEMILIHAN UMUM
}

\author{
Muhammad Syaefudin, Kadi Sukarna \\ Magister Hukum Universitas Semarang
}

\begin{abstract}
ABSTRAK
Penelitian ini bertujuan untuk menganalisa kewenangan Dewan Kehormatan Penyelenggara Pemilu dalam penegakan kode etik pelanggaran pemilihan umum. Undang-Undang Nomor 15 Tahun 2011 tentang Penyelenggara Pemilu memberikan warna baru dalam konteks pengaturan penyelenggara Pemilu. DKPP sebagai salah satu Lembaga Penyelenggara Pemilihan Umum yang tugasnya menangani permasalahan kode etik para penyelenggara pemilihan umum, dalam hal ini telah mencampuri wewenang dari KPUD Jawa Tengah, yang mana menurut Undang-Undang Nomor 15 Tahun 2011 tentang Penyelenggara Pemilihan Umum, keputusan DKPP tidak bisa memberikan implikasi hukum terhadap proses pemilu. Undang-Undang Nomor 15 Tahun 2011 yang mengatur tentang penyelenggara pemilu, telah mengatur tugas dan kewenangan dari DKPP dalam UU Nomor 15 Tahun 2011 Tentang Penyelenggara Pemilihan Umum. Sementara DKPP mengeluarkan Putusan yang memerintahkan KPU untuk melakukan peninjauan kembali untuk mengembalikan hak konstitusional dari Rojikin sebagai Calon Anggota DPRD Kota Semarang Jawa Tengah 2013, yang mana putusan tersebut merupakan bukan kewenangan dari DKPP, melainkan kewenangan dari KPU. Putusan yang dikeluarkan oleh DKPP yaitu memerintahkan KPU untuk segera melakukan Peninjauan Kembali untuk mengembalikan hak konstitusional Rojikin, telah mengakibatkan diloloskannya Rojikin sebagai Calon Calon Anggota DPRD Kota Semarang Jawa Tengah oleh KPU.
\end{abstract}

Kata Kunci : Kewenangan; pelanggaran pemilu; kode etik. 
$e-I S S N: 2621-4105$

\title{
AUTHORITY OF THE BOARD OF HONOR GENERAL ELECTION (DKPP) IN ENFORCING GENERAL ELECTION CODE OF VIOLATION
}

\author{
Muhammad Syaefudin, Kadi Sukarna \\ Master of Law, University of Semarang
}

\begin{abstract}
This study aims to analyze the authority of the Election Organizer Honorary Board in upholding the code of ethics of election violations.Law Number 15 Year 2011 on Election Organizer gives new color in the context of organizing election organizer. DKPP as one of the General Election Organizing Body whose duty is to handle the code of ethics of the election organizers, in this case has interfered withthe authority of the Central Java Election Commission, which according to Law Number 15 Year 2011 on General Election Organizer, the decision of DKPP can not provide the legal implications of the electoral process. Law Number 15 Year 2011 which regulatesthe election organizer, has regulated the duties and authorities of DKPP in Law Number 15 Year 2011 on the Organizer of General Election. While DKPP issued a Decision ordering the KPU to conduct a review to restore the constitutional rights of Rojikin as Candidate Members of Parliament of Semarang City Central Java 2013, which the decision is not the authority of DKPP, but the authority of theKPU. The decision issued by DKPP is to order the KPU to immediately conduct a Judicial Review to restore Rojikin's constitutional rights, resulting in the passage of Rojikin as Candidate Candidate for Semarang City DPRD Member of Central Java by KPU.
\end{abstract}

Keywords : Authority; enforcing general election; code of conduct. 


\section{A. PENDAHULUAN}

Pemilihan Umum di Indonesia dalam Undang-Undang Dasar Negra Republik Indonesia Tahun 1945 sebagaimana dikemukakan sebelum-nya bahwa pemilihan umum diselenggarakan dalam rangka memilih anggota DPR, DPD, DPRD, serta Presiden dan wakil Presiden. Hal ini secara langsung bahwa Undang-Undang Dasar Negara Republik Indonesia Tahun 1945 menyebut beberapa jenis pemilu di Indonesia. Pemilihan umum, DPR, DPD, DPRD, serta Pemilihan Umum Presiden dan Wakil Presiden masuk dalam rezim pemilu.

Adapun praktik pemilihan kepala daerah masuk dalam rezim pemerintahan daerah sebagaimana diatur dalam Undang-Undang Nomor 32 Tahun 2004 Tentang Pemerintahan Daerah. Namun, dalam perkembangannya pemilihan kepala daerah juga masuk dalam rezim pemilu. Undang-Undang Nomor 22 Tahun 2007 merupakan kompilasi dan penyempurnaan yang komprensif dalam satu UndangUndang terhadap semua pengaturan penyelenggara pemilu, inilah Undang-Undang yang menyebut pertama kali pilkada sebagai pemilu Kepala Daerah dan Wakil Kepala Daerah, meliputi :

1. pemilu DPR, DPD, DPRD ;

2. pemilu Presiden dan Wakil Presiden;

3. serta pemilu Kepala Daerah dan Wakil Kepala Daerah. ${ }^{1}$

Persoalan integritas penye-lenggara Pemilu menjadi hal penting yang harus mulai ditata sebagai upaya untuk membangun dan meningkatkan derajat integritas dan kualitas Pemilu. Sebagai upaya melakukan penataan integritas penyelengara Pemilu, maka lahirnya kode etik dan kelembagaan etik sebagai penyelenggara Pemilu mutlak harus ada dalam menjaga kemandirian, integritas, dan kredi-biltas penyelenggara Pemilu.

Undang-Undang Nomor 15 Tahun 2011 tentang Penyelenggara Pemilu memberikan warna baru dalam konteks pengaturan penye-lenggara Pemilu. Kehadiran Dewan Kehormatan Penyelenggara Pemilu ( DKPP) yang permanen, sebagai kesatuan fungsi dengan penye-lenggara Pemilu merupakan langkah

1 Suharizal, “ Pemilukada : Regulasi, Dinamika, dan Konsep Mendatang “, (.Jakarta : Rajawali Pers, 2012 ), hal 76 
progresif dalam upaya untuk men jawab atas pentingnya menjaga kemandirian, integritas, dan kredi-bilitas penyelenggara Pemilu. Penye-lenggaraan Pemilu yang berkualitas diperlukan sebagai sarana untuk mewujudkan kedaulatan rakyat dalam pemerintahan negara yang demokratis.

Prinsip pengadilan etika yang modern itu ada keterbukaan, trans-paransi. Dalam konteks Indonesia, proses pengadilan etika di DKPP dilakukan secara terbuka. Memang masing-masing lembaga negara punya komisi etik, tetapi masih dijalankan secara tertutup. Di DKPP, ada terobosan bahwa pengadu, teradu, saksi, dan pihak-pihak terkait, termasuk media, bisa hadir secara luas. DKPP adalah pengadilan etika untuk menjaga kehormatan,integritas, dan kredibilitas penyelenggara pemilu. Ada proses pendidikan politik secara tidak langsung lewat sidang-sidang yang dilakukan secara terbuka itu.

Dalam konteks tersebut DKPP dibentuk. Tugas dan kewenangan DKPP berkaitan dengan orang per orang pejabat penyelenggara pe-milihan umum, baik KPU maupun Bawaslu. DKPP merupakan produk wacana perbaikan kualitas demokrasi khususnya penyelenggaraan Pemilu. Pemilu seakan-akan menjadi beban sejarah politik tersendiri bagi perubahan, bahkan berharganya pemilu dibutuhkan lembaga khusus yang permanen melakukan penegak-an kode etik guna menghasilkan Pemilu yang tidak saja luber jurdil tapi mewujudkan proses dan hasil pemimpin yang betul-betul ber-martabat.

Meskipun demikian apa yang sudah dilakukan DKPP, bukanlah tanpa kritik. Kasus Calon Anggota DPRD Kota Semarang Rojikin yang tidak diloloskan sebagai peserta dalam Pemilihan Umum Anggota DPRD kota Semarang oleh KPUD Jawa Tengah, karena alasan adanya dualisme partai pendukung, melapor-kan gugatannya ke DKPP. Sidang gugatan pelanggaran kode etik yang diadukan bakal Calon Anggota DPRD Kota Semarang Rojikin itu, mengungkap sejumlah fakta tentang kurang tertibnya administrasi yang dilakukan Komisi Pemilihan Umum (KPU) Provinsi Jawa Tengah dalam melaksanakan tahapan verifikasi. Tuntutan Rojikin untuk melakukan kaji ulang terhadap putusan KPU Jawa Tengah tentang penetapan calon Anggota DPRD kota Semarang, dikabulkan sebagian oleh DKPP, dimana DKPP menjatuhkan sanksi peringatan ke Abdoel Koliq menurut hasil putusan DKPP 
Nomor 132 / DKPP-PKE-II / 2013. Akhirnya pada tanggal 3 Desember 2013, KPU membatalkan keputusannya yang tertuang dalam Putusan KPU Jateng Nomor 547 / KPU Kota-012.329521 / X / 2013 dan menetapkan Calon Anggota DPRD kota Semarang Rojikin sebagai peserta Calon Anggota DPRD Kota Semarang Jawa Tengah tahun 2013 menurut putusan Nomor 552 / KPU Kota-021.329521 / X / 2013. Putusan DKPP mengenai pemberian perintah kepada KPU untuk segera melolos-kan Rojikin sebagai peserta Pemilihan Umum Calon Anggota DPRD Kota Semarang, menuai kritik. $^{2}$

Hal ini menimbulkan persoalan, DKPP sebagai salah satu Lembaga Penyelenggara Pemilihan Umum yang tugasnya menangani perma-salahan kode etik para penye-lenggara pemilihan umum, dalam hal ini telah mencampuri wewenang dari KPUD Jawa Tengah, yang mana menurut Undang-Undang Nomor 15 Tahun 2011 tentang Penyelenggara Pemilihan Umum, keputusan DKPP tidak bisa memberi-kan implikasi hukum terhadap proses pemilu.

Agar pembahasan dalam penelitian ini tidak terlalu meluas, maka penelitian ini dibatasi pada Putusan DKPP Nomor 132 / DKPP-PKE-II / 2013 terhadap kewenangan DKPP yang diatur dalam Undang-Undang Nomor 15 Tahun 2011 tentang Penyelenggara Pemilu dan dampak atau pengaruh Putusan DKPP Nomor 132 / DKPP-PKE-II / 2013 terhadap pelaksanaan Pemilu Calon Anggota DPRD di Kota Semarang Jawa Tengah.

\section{B. PERMASALAHAN}

1) Bagaimanakah Pelaksanaan Kewenangan Dewan Kehor-matan Penyelenggara Pemilu (DKPP) Dalam Menyelesaikan Pelanggaran Pemilihan Umum Oleh Anggota Komisi Pemilihan Umum Kota Semarang?

2) Bagaimana Tinjauan Putusan DKPP Nomor 132 / DKPP-PKEII / 2013 dengan kewenangan DKPP yang diatur dalam Undang Undang Nomor 15 Tahun 2011 tentang Penyelenggara Pemilu?

\section{TINJAUAN PUSTAKA}

\section{Demokrasi Dalam Pemilu}

\footnotetext{
${ }^{2}$ Soal Rojikin DKPP Kritik KPU Jateng, ( http:// www.republika.co.id / berita / nasional / jawa-tengah / 13 / 07 / 29 /, diakses pada 24 Januari 2017 ).
} 
Demokrasi dari segi etimologi (bahasa) berasal dari dua kata demos artinya rakyat dan cratos / cratein berarti pemerintahan. Berarti pemerintah yang dilakukan oleh rakyat. Demokrasi diwujudkan dengan adanya pemerintahan yang bersendikan perwakilan rakyat, yang kekuasaan dan wewenangnya berasal dari rakyat. Oleh karena itu demokrasi mensyaratkan adanya pemilihan umum untuk memilih wakil-wakil rakyat tersebut yang harus diselenggarakan secara bebas, rahasia, jujur, dan adil. Secara terminologis pengertian demokrasi sebagai berikut $:^{3}$

a. Menurut Josefh A. Schmeter, demokrasi merupakan suatu perencanaan institusional untuk mencapai keputusan politik dimana individu-individu memper-oleh kekuasaan untuk memutusk-an dengan cara perjuangan kompetitif atas suara rakyat ;

b. Menurut Sidney Hook, demokrasi adalah bentuk pemerintahan dimana keputusan-keputusan didasarkan pada kesepakatan mayoritas yang diberikan secara bebas dari rakyat dewasa ;

c. Menurut Philippe C. Schmitter dan Terry Lynn Karl, demokrasi merupakan suatu system peme-rintahan dimana pemerintah dimintai tanggung jawab atas tindakan-tindakan mereka di wilayah publik oleh warga negara, yang bertindak secara tidak langsung melalui kompetisi kerja-sama dengan para wakil mereka yang telah terpilih.

Faham demokrasi tersebut sudah lahir sejak berpuluh-puluh tahun sebelum Masehi hingga sekarang abad ke 21 dan selalu dipikirkan serta dibicarakan orang maka wajarlah, melalui perjalanan waktu yang semakin lama itu, demokrasi mengalami perkembangan pemikiran. Ternyata setelah diuji dari zaman ke zaman, bahkan acapkali mengalami peperangan-peperangan besar, faham demokrasi itu dapat diterima oeh sebagian besar umat manusia.

Dari pendapat para ahli di atas terdapat benang merah atau titik singgung tentang pengertian demo-krasi yaitu rakyat sebagai pemegang kekuasaan, pembuat dan penentu keputusan dan kebijakan tertinggi dalam penyelenggaraan negara dan pemerintahan serta pengontrol ter-hadap pelaksanaan kebijakannya baik yang dilakukan secara langsung oleh rakyat atau mewakilinya melalui lembaga perwakilan.

\footnotetext{
${ }^{3}$ Tim Penyusun PUSLIT IAIN Syarif Hidayatullah, “ Demokrasi, HAM \& Masyarakat Madani “, cet.III, ( Jakarta : IAIN Jakarta Press, 2000 ), hal 162.
} 
e-ISSN : 2621-4105

\section{Etika Dalam Profesi Hukum}

Dalam Kamus Besar Bahasa Indonesia dikatakan bahwa etika adalah ilmu tentang apa yang baik dan apa yang buruk dan tentang hak dan kewajiban moral (akhlak). Dalam kaitannya dengan kata etika tersebut, Bartens menjelaskan etika berasal dari Yunani kuno yaitu ethos dalam bentuk tunggal yang berarti adat kebiasaan, adat istiadat, akhlak yang baik. Bentuk jamak dari ethos adalah ta etha artinya adat kebiasaan. Dari bentuk jamak ini terbentuklah istilah etika yang oleh filsuf Yunani, Aristoteles sudah dipakai untuk menujukkan sifat moral. ${ }^{4}$

Istilah etika menghubungkan penggunaan akal budi perseorangan dengan tujuan untuk menentukan kebenaran atau kesalahan dan tingkah laku seseorang terhadap orang lain. Pada hakikatnya segala ucapan etika itu relatif belaka, lazimnya nilai ucapan senantiasa terikat pada suatu tempat dan waktu tertentu. Selanjutya baik atau buruk-nya kelakuan seorang manusia hanya dipastikan dari sudut pandang masyarakat belaka.

Jika tiga pernyataan tersebut itu diintisarikan, sampailah pada suatu fungsi utama etika, sebagai-mana disebutkan oleh Magnis Suseno, yaitu untuk membantu kita mencari orientasi secara kritis dalam berhadapan dengan moralitas yang membingungkan. Disini terlihat bahwa etika adalah pemikiran sis-tematis tentang moralitas, dan yang dihasilkannya secara langsung bukan kebaikan, melainkan suatu penger-tian yang lebih mendasar dan kritis. Pengertian demikian perlu dicari dengan alasan :

1) Kita hidup dalam masyarakat yang semakin pluralistik, juga dalam bidang moral, sehingga kita bingung harus mengikuti moraitas yang mana.

2) Modernisasi membawa perubahan besar dalam struktur kebutuhan dan nilai masyarakat yang akibatnya menantang pandangan pandangan moral tradisional.

3) Adanya berbagai ideology yang menawarkan diri sebagai penun-tun hidup, yang masing-masing dengan ajarannya sendiri tentang bagaimana manusia harus hidup, dan

\footnotetext{
${ }^{4}$ Supriadi, “ Etika \& Tanggung Jawab Profesi Hukum di Indonesia “, cet.II, (.Jakarta : Sinar Grafika, 2008 ), hal 7.
} 
4) Etika juga diperlukan oleh kaum agama yang di satu pihak menemukan dasar kemantapan mereka dalam iman kepercayaan mereka, di lain pihak sekaligus mau berpartisipasi tanpa takut-takut dan dengan tidak menutup diri dalam dimensi kehidupan masyarakat yang sedang berubah itu. ${ }^{5}$

Etika dimasukkan dalam disiplin pendidikan hukum disebab-kan, belakangan terlihat adanya gejala penurunan etika dikalangan aparat penegak hukum, yang mana hal ini tentunya akan merugikan bagi pembangunan masyarakat Indonesia. Suatu pendidikan professional tanpa pendidikan mengenai tanggung jawab dan etika professional tidak lengkap. Pendidikan keterampilan hukum dibidang teknis dibidang hukum yang mengabaikan segi yang menyangkut tanggung jawab sese-orang terhadap orang yang diprcayakan kepedanya dan profesi-profesinya pada umumnya serta nilainilai dan ukuran etika yang harus menjadi pedoman dalam men-jalankan profesinya hanya akan menghasilkan tukang-tukang yang terampil belaka dibidang hukum dan profesinya. ${ }^{6}$

\section{Lembaga Negara}

Negara merupakan gejala kehidupan umat manusia di se-panjang sejarah umat manusia. Konsep negara berkembang mulai dari bentuknya yang paling sederhana sampai ke yang paling kompleks di zaman sekarang. Se-bagai bentuk organisasi kehidupan bersama dalam masyarakat, negara selalu menjadi pusat perhatian dan objek kajian bersamaan dengan berkembangnya ilmu pengetahan umat manusia. $^{6}$

Negara merupakan integrasi dari kekuasaan politik, ia adalah organisasi pokok dari kekuasaan politik. Negara adalah agency (alat) dari masyarakat yang mem-punyai kekuasaan untuk mengatur hubungan-hubungan manusia dalam masyarakat dan menertibkan gejala-gejala kekuasaan dalam masyarakat. Negara adalah organisasi yang dalam suatu wilayah dapat memaksakan kekuasannya secara sah.

\section{PEMBAHASAN}

5 Jimly Asshiddiqie, Pengantar Ilmu Hukum Tata Negara, cet.V, ( Jakarta : PT. Raja Grafindo Persada, 2009 ), hal 9. 
e-ISSN : 2621-4105

\section{Pelaksanaan Kewenangan Dewan Kehormatan Penyelenggara Pemilu (} DKPP ) Dalam Menyelesaikan Pelanggaran Pemilihan Umum Oleh Anggota

\section{Komisi Pemilihan Umum Kota Semarang}

Kewenangan Dewan Kehor-matan Penyelenggara Pemilu sbagai penyelenggara pemilu diatur dalam Undang-Undang Nomor 15 Tahun 2011 tentang Penyelenggara Pemilu pasal 1 ayat 22, yang berbunyi : Dewan Kehormatan Peyelenggara Pemilu yang selanjutnya disingkat DKPP adalah lembaga yang ber-tugas menangani pelanggaran kode etik penyelenggara pemilu dan merupakan satu kesatuan fungsi penyelenggaraan pemilu.

Dalam hal ini, penulis akan membahas mengenai kewenangan DKPP yang dalam salah satu putusannya, menurut penulis telah melanggar atau melebihi batas kewenangannya, yaitu dalam kasus Pemilu Anggota DPRD kota Sema-rang Jawa Tengah 2013. Dan lebih terfokus kepada gugatan atau laporan yang diajukan Calon Anggota DPRD Jawa Tengah, Rojikin kepada DKPP.

Pada tanggal 3 Desember 2013 DKPP mengumumkan hasil gugatan yang diajukan oleh Anggota DPRD kota Semarang, Rojikin melalui surat putusannya No. 132 / DKPP-PKE-II / 2013, memutuskan :

1. Mengabulkan pengaduan peng-adu untuk sebagian ;

2. Menjatuhkan sanksi peringatan kepada teradu atas nama Abdoel Koliq ;

3. Memerintahkan kepada Komisi Pemilihan Umum Republik Indonesia untuk melakukan peninjauan kembali secara cepat dan tepat terhadap keputusan KPUD Jawa Tengah sesuai maksud, prinsip, dan etika penye-lenggara pemilu dalam rangka pemulihan hak konstitusional Sdr. Rojikin ;

4. Memerintahkan kepada Komisi Pemilihan Umum untuk meng-ambil alih tanggung jawab KPU Provinsi Jawa Tengah untuk sementara, dan melaksanakan putusan ini sebagaimana mesti-nya, serta kepada Badan Pengawas Pemilihan Umum Republik Indonesia untuk mengawasi keputusan ini.

Putusan pada point 4 inilah yang akan penulis bahas. Kata-kata “ memerintahkan kepada KPU " membuat penulis merasa bahwa DKPP telah melebihi kewenangan sebagai Dewan Etik Pemilihan Umum. Secara kewenangan yang diatur dalam undang-undang, memang DKPP berwenang untuk menangani 
kasus pelanggaran kode etik yang terjadi di KPUD Jawa Tengah. Dalam Pasal 109 ayat (2) UU Nomor 15 Tahun 2011 Tentang Penyelenggara Pemilu yang berbunyi, “ DKPP dibentuk untuk memeriksa dan memutuskan peng-aduan dan/atau laporan adanya dugaan pelanggaran kode etik yang dilakukan oleh anggota KPU, anggota KPU Provinsi, anggota KPU Kabupaten / Kota, anggota PPK, anggota PPS, anggota PPLN, anggota KPPS, anggota KPPSLN, anggota Bawaslu, anggota Bawaslu Provinsi, dan anggota Panwaslu Kabupaten / Kota, anggota Panwaslu Kecamatan, anggota Pengawas Pemilu Lapangan, dan anggota Pengawas Pemilu Luar Negeri.

Dari uraian tugas dan wewe-nang DKPP di atas, memang tidak disebutkan mengenai putusan yang di luar pelanggaran etik. Kalimat " Memerintahkan kepada Komisi Pemilihan Umum Republik Indonesia untuk melakukan peninjauan kembali secara cepat dan tepat terhadap keputusan KPUD Jawa Tengah " menurut penulis adalah hal yang tidak tepat dikeluarkan oleh sebuah lembaga penegakkan kode etik, karena putusan itu telah diluar kewenangan putusan sebuah lem-baga penegak etik.

Menurut Pakar Hukum Tata Negara dari Universitas Surabaya, Prof. Eko Sugitario, SH, M.Hum, berpendapat sebenarnya sidang DKPP ini bisa dipertanyakan, " karena bukan kewenangan DKPP untuk menentukan soal keputusan KPU, itu merupakan ranah PTUN. DKPP hanya mengadili pelanggaran etika penyelenggara pemilu."

Mantan Menteri Kehakiman dan HAM, Yusril Ihza Mahedra berpendapat : “ DKPP tidak bisa membatalkan keputusan yang dibuat KPU. DKPP sesuai fungsinya hanya memutuskan masalah kode etik. MK mengadili hasil pemilu, sementara yang mengadili keputusan lembaga negara ( KPU Jateng ) adalah peradilan tata usaha negara."

Menurut Direktur Eksekutif Perkumpulan untuk Pemilu dan Demokrasi, Titi Anggraini, mengata-kan “ Putusan tersebut memberi kesan DKPP ingin melibatkan diri sebagai peradilan administrasi pemilihan umum. Padahal secara undang-undang, jelas disebutkan bahwa kewenangan DKPP adalah dalam pemeriksaan dugaan pelang-garan kode etik." 
Pendapat ketiga ahli hukum tata negara tersebut dapat kita jadikan pertimbangan bahwa tugas DKPP benar adalah megenai penegakan kode etik para penye-lenggara pemilu, dan diluar putusan yang diluar etika penyelenggara pemilu, merupakan bukan kewe-nangan dari DKPP. Walaupun salah satu tugas DKPP dalam UU Nomor 15 Tahun 2011 pasal 111 ayat 3 adalah “ Menyampaikan putusan kepada pihak-pihak terkait untuk ditindak lanjuti ”, akan tetapi dengan adanya kalimat diatas, penulis menafsirkan bahwa kalau memang ada suatu temuan diluar kewenangan DKPP, berarti temuan itu hanya bisa disampaikan kepada lembaga yang terkait, yang berwenang untuk mengurus dan memutuskannya. Dan putusan itu bersifat rekomendasi, bukan perintah yang wajib harus dilaksanakan.

\section{Tinjauan Putusan DKPP Nomor 132 / DKPP-PKEII / 2013 dengan}

\section{kewenangan DKPP yang diatur dalam Undang-Undang Nomor 15 Tahun 2011 tentang Penyelenggara Pemilu}

Dikabulkannya sebagian gugat-an Rojikin oleh DKPP, pastinya akan memberikan akibat atau implikasi terhadap proses pemilu di Provinsi Jawa Tengah. Adapun berbagai dampak atau implikasi dari putusan DKPP Nomor 132 / DKPP-PKE-II / 2013, yaitu :

1. Diloloskannya Rojikin sebagai Calon Anggota DPRD Kota Semarang Jawa Tengah 2013.

2. Anggota KPUD Kota Semarang Jawa Tengah Abdoel Koliq ( Teradu ) diberikan sanksi per-ingatan; dan

3. Pelaksanaan putusan ini di ambil alih oleh KPU pusat dan Bawaslu sebagai pengawas dari pelaksaan putusan tersebut.

Implikasi putusan yang akan penulis bahas disini adalah mengenai diloloskannya Rojikin sebagai Calon Anggota DPRD Kota Semarang Jawa Tengah 2013. Memang bukan semata-mata karena putusan DKPP tersebut Rojikin bisa lolos dan mengikuti Pemilu ini, tetapi karena adanya unsur instruksi atau perintah dari putusan DKPP ini yang akhirnya membuat KPU untuk melakukan peninjauan kembali terhadap putusan KPUD Jawa Tengah Nomor Nomor 547 / KPU Kota-012.329521 / X / 2013. Dan melalui putusannya Nomor 
552 / KPU Kota-021.329521 / X / 2013, KPU menyatakan melolos-kan Rojikin sebagai Calon Anggota DPRD Kota Semarang Jawa Tengah 2013.

Tentu saja putusan KPU ini menuai berbagai kritik dikalangan ahli hukum tata negara. Bukan karena persoalan personal calonnya, tetapi mengenai prosedur pelolosan Rojikin yang awal mulanya mendapat perintah dari DKPP untuk segera melakukan peninjauan kembali terhadap putusan KPU kota Semarang Jawa Tengah yang enggan meloloskan Rojikin.

Seperti yang telah dijelaskan diatas mengenai tugas dan kewe-nangan DKPP, bahwa implikasi putusan DKPP tidak boleh mengenai soal proses pemilu. Kewenangannya hanya boleh memutus dan mem-berikan sanksi soal etika penyelenggara pemilu saja.

Objek Perkara di DKPP juga tidak tergantung kepada tempos delicti atau saat kapan suatu perbuatan melanggar kode etik. Misalnya, meskipun Pemilihan Wali-kota Depok telah berlangsung dua tahun sebelumnya dan putusan sengketa hasil pemilu telah bersifat final dan mengikat berdasarkan putusan Mahkamah Konstitusi yang telah dilaksanakan dengan sebaik-baiknya oleh Komisi Pemilihan Umum, tetapi dikemudian hari ter-bukti adanya pelanggaran kode etika yang dilakukan oleh Ketua KPU Depok dalam proses pemilihan Walikota Depok 2 tahun sebelumnya itu, tetap saja DKPP berwenang memeriksa dugaan pelanggaran kode etik yang terjadi 2 tahun sebelumnya itu.

Ternyata, dari pemeriksaan yang bersifat terbuka oleh DKPP, terbukti bahwa Ketua KPU Kota Depok memang telah melanggar kode etika, maka atas dasar itu ia diberhentikan berdasarkan putusan DKPP yang bersifat final dan mengikat. Namun, putusan DKPP itu tidak dapat dijadikan alasan untuk memberhentikan walikota yang telah terpilih dan bahkan telah menjalan-kan tugasnya selama 2 tahun, meskipun ketua KPU Kota Depok telah diberhentikan berdasarkan putusan DKPP. Mengapa demikian ? Sebabnya adalah bahwa antara persoalan pelanggaran kode etik aparat KPU dan proses pemilihan Walikota dan dengan persoalan sengketa mengenai hasil pemilihan itu, sama sekali tidak dapat dikaitkan berdasarkan prinsip sebab-akibat atau kausalitas. 
Tetapi pada kenyataannya, Prof. Jimly Asshiddiqie selaku ketua DKPP memberikan putusan yang berbeda, dalam menangani kasus Rojikin tersebut. Jelas-jelas ia me-negaskan bahwa antara persoalan pelanggaran kode etik aparat KPU dan proses persoalan sengketa mengenai hasil pemilihan itu, sama sekali tidak dapat dikaitkan berdasar-kan prinsip sebab-akibat kausalitas.

Kata pengembalian hak kons-titusional lah yang dijadikan alasan Prof. Jimly Asshiddiqie sebagai pimpinan rapat pleno kasus ini. Kata-kata yang penulis kutip dari putusan yang dikeluarkan DKPP adalah “ Menghilangkan hak seorang warga negara yang memenuhi persyaratan, bukan hanya menciderai demokrasi, tetapi merupakan pembunuhan politik seseorang. Dengan mendasarkan diri pada keterangan, bukti-bukti dan pendapat ahli di dalam persidangan, terhadap keputusan mayoritas ang-gota KPU Jateng yang kemudian menjadi keputusan KPU Jateng yang "menghilangkan " hak politik Rojikin, DKPP dengen kesadaran dan keyakinan penuh berpendapat, bahwa negara berkewajiban memulihkan hak tersebut Negara harus menempuh segala upaya untuk mengembalikan hak politik warga negara atas nama Rojikin sebagai Calon Anggota DPRD, agar hak politik warga negara tidak dibunuh negara melalui penyelenggara negara dalam penyeleggaraan pemilu."

Putusan tersebut memang mengandung maksud baik, yaitu untuk pengembalian hak konstitu-sional dari Rojikin. Tapi menurut penulis dengan adanya kata memerintahkan untuk segera me-lakukan peninjauan kembali, seperti ada hal paksaan dan kewajiban untuk segera meloloskan Rojikin sebagai Calon Anggota DPRD Kota Semarang Jawa Tengah 2013, yang menurut UndangUndang DKPP tidak diberikan kewenangan soal itu.

Proses penyelesaian secara hukum atas pelanggaran kode etik tersebut adalah berdasarkan Undang Undang Nomor 8 Tahun 2012 tentang Pemilihan Umum Anggota DPR, DPD, dan DPRD sebagai dasar hukum pelaksanaan pemilihan umum untuk memilih anggota DPR, DPD dan DPRD di Indonesia salah satu muatannya adalah penyelesaian pelanggaran kode etik pemilu. Di dalam undang-undang tersebut pada Bab XXI Paragraf 2 pasal 252 menyebutkan bahwa : 
1) Pelanggaran kode etik penye-lenggara Pemilu sebagaimana dimaksud dalam Pasal 251 diselesaikan oleh Dewan Kehor-matan Penyelenggara Pemilu.

2) Tata cara penyelesaian pelanggaran kode etik penye-lenggara Pemilu sebagaimana dimaksud pada ayat (1) dilaksanakan sesuai dengan ketntuan Undang-Undang tentang Penyelenggara Pemilu.

Berdasarkan pasal diatas ter-kait penyelesaian pelanggaran kode etik pemilu, diterangkan bahwa pelanggaran kode etik pemilu diselesaikan oleh Dewan Kehor-matan Penyelenggara Pemilu. Hal ini di pertegas juga pada Pasal 109 Ayat (2) Undang Undang No. 15 Tahun 2011 Tentang Penyelenggara Pemilu yaitu : “ DKPP dibentuk untuk meme-riksa dan memutuskan pengaduan dan / atau laporan adanya dugaan pelanggaran kode etik yang dilaku-kan oleh anggota KPU, anggota KPU Provinsi, anggota KPU Kabupaten / Kota, anggota PPK, anggota PPS, anggota PPLN, anggota KPPS, anggota KPPSLN, anggota Bawaslu, anggota Bawaslu Provinsi dan anggota Panwaslu Kabupaten / Kota, anggota Panwaslu Kecamatan, anggota Pengawas Pemilu Lapangan dan anggota Pengawas Pemilu Luar Negeri ”.

Dari uraian diatas telah di-ketahui mekanisme pelaporan pelanggaran kode etik pemilihan umum di Indonesia. Abdoel Kholiq merupakan salah satu penyelenggara pemilihan umum yang diadukan ke Dewan Kehormatan Penyelenggara Pemilu terkait pelanggaran kode etik penyelenggara pemilihan umum dan DKPP menjatuhkan sanksi peringatan keras kepada Teradu selaku Anggota KPU Kota Semarang.

\section{PENUTUP}

Undang-Undang Nomor 15 Tahun 2011 yang mengatur tentang penyelenggara pemilu, telah mengatur tugas dan kewenangan dari DKPP dalam UU Nomor 15 Tahun 2011 Tentang Penyelenggara Pemilihan Umum. Sementara DKPP menge-luarkan Putusan yang meme-rintahkan KPU untuk melakukan peninjauan kembali untuk mengembalikan hak konstitusional dari Rojikin sebagai Calon Anggota DPRD Kota Semarang Jawa Tengah 2013, yang mana putusan tersebut merupakan bukan kewenangan dari DKPP, melainkan kewenangan dari KPU. 
Putusan yang dikeluarkan oleh DKPP yaitu memerintahkan KPU untuk segera melakukan Peninjauan Kembali untuk men-gembalikan hak konstitusional Rojikin, telah mengakibatkan diloloskannya Rojikin sebagai Calon Calon Anggota DPRD Kota Semarang Jawa Tengah oleh KPU. Dewan Kehormatan Penye-lenggara Pemilu ( DKPP ) telah melaksanakan kewenangannya sesuai dengan Undang-Undang Nomor 15 Tahun 2011 tentang Penyelenggara Pemilihan Umum dalam menyelesaikan pelang-garan pemilu yang dilakukan oleh Abdoel Kholiq yang merupakan salah satu anggota KPU Kota Semarang tersebut. 


\section{DAFTAR PUSTAKA}

\section{BUKU}

Abdullah, Rozali. Mewujudkan Pemilu Yang Lebih Ber-kualitas ( Pemilu Legislatif ), Jakarta : Rajawali Press, 2009.

Asshiddiqie, Jimly. Pengantar Ilmu Hukum Tata Negara “, cet.V, Jakarta : PT. Raja Grafindo Persada, 2009.

Asshiddiqie, Jimly. Perkembangan \& Konsolidasi Lembaga Negara Pasca Reformasi, Jakarta : Konstitusi Press, 2006.

Budiardjo, Miriam. Dasar-Dasar Ilmu Politik, cet.VI, Jakarta : PT. Gramedia Pustaka Utama, 2005.

Gaffar, Jenedjri M. Demokrasi Konstitusional : Praktik Ketata-negaraan Indonesia setelah Perubahan UUD 1945, Jakarta : Konstitusi Press, 2012.

Kansil, C.S.T. dan Christine S.T. Kansil, Pokok-Pokok Etika Profesi Hukum, cet.II, Jakarta : PT Pradnya Paramita, 2003.

Subekti, Valina Singka. Menyusun Konstitusi Transisi, Pergulatan Kepentingan dan Pemikiran Dalam Proses Perubahan UUD 1945, Jakarta : Rajawali Press, 2007.

Suharizal, Pemilukada : Regulasi, Dinamika, dan Konsep Men-datang, Jakarta : Rajawali Pers, 2012.

Supriadi, Etika \& Tanggung Jawab Profesi Hukum di Indonesia, cet.II, Jakarta : Sinar Grafika, 2008.

Tim Penyusun PUSLIT IAIN Syarif Hidayatullah, Demokrasi, HAM \& Masyarakat Madani, cet.III, Jakarta : IAIN Jakarta Press, 2000.

\section{UNDANG-UNDANG}

Peraturan DKPP Nomor 1 Tahun 2012 tentang Kode Etik Penyelenggara Pemilu. Peraturan KPU Nomor 13 Tahun 2012 tentang Kode Etik Penyelenggara Pemilu. Putusan DKPP Nomor 132 / DKPP-PKE-II / 2013 tentang KPUD Jawa Tengah.

Putusan KPU Jawa Tengah Nomor : 552 / KPU Kota-021.329521 / X / 2013 tentang Penetapan Calon Anggota DPRD Kota Semarang Jawa Tengah.

Undang-Undang Republik Indonesia Nomor 15 Tahun 2011 Tentang Penyelenggara Pemilu.

\section{INTERNET}

Disetir Sidang DKPP, ( http:// semarangpagi. Com / index. php? read, diakses pada 28 Januari 2018 ).

inilah pernyataan yusril soal gugatan, ( http:// nasional. inilah. Com / read / detail / 2015977 / diakses pada 28 Januari 2018. 
e-ISSN : 2621-4105

Kasus Rojikin Putusan DKPP. ( http:// www. yiela. Com / view / 3211907 /, diakses pada 28 Januari 2018 ).

Soal Rojikin DKPP Kritik KPU Jateng, ( http:// www.republika.co.id / berita / nasional / jawa-tengah / 13 / 07 / 29 /, diakses pada 24 Januari 2017 ). 